\title{
Analisis Materi Ajar Kimia SMA/MA Kelas X Pada Konsep Stoikiometri
}

Siti Fatimah Indah Sari*, Abdul Hadjranul Fatah, Maya Erliza Anggraeni Program Studi Pendidikan Kimia, Jurusan Pendidikan MIPA, Fakultas Keguruan dan Ilmu Pendidikan, Universitas Palangka Raya, Jl. H. Timang Kampus UPR Kalimantan Tengah, Indonesia E-mail: sitifatimahindahsari@gmail.com

Diterima: 05 Maret 2020; Disetujui: 20 Maret 2020; Diterbitkan: 29 Maret 2020

\begin{abstract}
ABSTRAK
Penelitian ini bertujuan untuk melakukan analisis materi ajar pada buku teks kimia SMA. Instrumen yang digunakan yaitu tabel identifikasi proposisi mikro-makro, model struktur makro wacana, dan tabel identifikasi proposisi yang berpotensi kesalahan konsep (miskonsepsi). Data yang diperoleh dianalisis secara deskriptif. Hasil penelitian menunjukkan Label konsep yang dianalisis secara keseluruhan berjumlah 46 label konsep, label konsep pada buku teks A dan buku teks B yang sesuai terhadap silabus kurikulum 2013 masing-masing berjumlah 34 dan 37. Label konsep yang hanya terdapat pada buku A berjumlah 9 dan semuanya sesuai terhadap silabus kurikulum 2013, dan label konsep yang hanya terdapat pada buku B, berjumlah 12 dan semuanya sesuai dengan Silabus Kurikulum 2013. Berdasarkan struktur makro wacana untuk topik stoikiometri pada buku teks A pembahasan konsep pada dimensi elaborasi mencapai level 5 dan dimensi progresi terdapat 4 konsep pada level 2 sebagai cakupan bahasan, pada buku teks B sajian materi pada dimensi elaborasi mencapai level 4, dan dimensi progresi pada level 2 terdapat 8 konsep.
\end{abstract}

Kata Kunci: analisis materi ajar, buku teks, stoikiometri

\section{PENDAHULUAN}

Kimia merupakan salah satu mata pelajaran IPA (Ilmu Pengetahuan Alam) yang berada diantara fenomenalogi dan abstrak. Konsep kimia mempelajari fenomena yang tidak dapat diamati secara langsung, seperti struktur molekul, dan interaksi antar atom, molekul serta ion. Dasar dalam memahami konsep tersebut adalah pemberian makna pada sesuatu yang tidak dapat dilihat, tidak dapat disentuh, dan membuat gambaran untuk menghubungkan fenomena yang bersifat molekuler (Gkitzia, et al 2011)

Ilmu kimia merupakan ilmu yang sangat penting dalam kehidupan seharihari. Didalamnya mempelajari banyak konsep, mulai dari konsep sederhana sampai konsep yang lebih kompleks dan abstrak. Konsep-konsep tersebut saling berkaitan dan berjenjang. Konsep-konsep dasar kimia mendasari dan membangun konsep yang lebih kompleks, apabila peserta didik salah dalam memahami konsep dasar kimia tersebut, maka memungkinkan sekali konsep yang lebih kompleks sulit dipahami atau tidak dapat dipahami dengan benar. Pemahaman konsep yang salah atau berbeda dengan pemahaman konsep secara ilmiah disebut miskonsepsi (Tekkaya, 2002). Miskonsepsi pada peserta didik dalam belajar kimia dapat terjadi karena konsep kimia yang kompleks, bersifat abstrak, dan saling berkaitan. 
Stoikiometri merupakan salah satu materi dalam kurikulum kimia kelas X IPA SMA. Bennerje, et al (2001) mengatakan bahwa materi stoikiometri adalah salah satu materi yang paling sulit dalam program kimia dasar dan berbagai penelitian telah menyelidiki siswa bahkan mahasiswa mengalami kesulitan. Demikian pula Ahmad (1998) menyatakan bahwa materi stoikiometri merupakan salah satu topik yang sulit dipahami oleh mahasiswa semester I dan II pada mata kuliah Kimia Dasar I dan II.

Penelitian yang dilakukan oleh Yelli (2016) mengungkapkan bahwa siswa mengalami kesulitan dalam sub pokok materi Stoikiometri tentang Hukum Dasar Kimia yaitu: a) menentukan massa hasil reaksi jika diketahui massa zat-zat yang bereaksi $(37 \%)$, b) menentukan massa zat hasil reaksi jika diketahui perbandingan massa zat-zat yang bereaksi serta massa reaktan yang tersedia (89\%), c) menentukan mol hasil reaksi jika diketahui mol zat-zat yang bereaksi (85\%).

Peraturan Menteri Pendidikan Nasional Tahun 2007, Buku Teks pelajaran yang sudah ditetapkan pemerintah dan telah memenuhi syarat untuk digunakan dalam proses belajar mengajar. Daftar Buku Teks pelajaran yang layak digunakan sesuai dengan kurikulum 2013 telah ditetapkan dalam Permendikbud RI Nomor 1 Tahun 2015. Dalam peraturan tersebut tidak tercantum Buku Teks pelajaran kimia yang layak digunakan sesuai dengan kurikulum 2013. Oleh karena itu siswa mengalami kesulitan belajar konsep bukan hanya disebabkan oleh proses belajar saja, namun juga dapat dipengaruhi oleh sumber belajar seperti Buku Teks yang digunakannya. Salah satu cara yang dilakukan untuk mengurangi kesulitan pada konsep kimia yaitu dengan meninjau atau menganalisis kembali materi ajar yang disajikan dalam Buku Teks kimia apakah sajian materi dari kata atau kalimat yang disajikan dalam buku dapat diterima dengan baik oleh siswa atau siswa kurang memahami penjelasan yang disajikan dalam buku, sehingga hal yang dilakukan yaitu dengan menganalisis Buku Teks ini yang dilakukan dengan cara yaitu analisis wacana proposisi mikro dan makro, analisis struktur wacana dan analisis proposisi yang berpotensi menimbulkan kesalahan konsep.

Buku Teks yang dianalisis adalah Buku Teks kimia SMA kurikulum 2013 pengarang Unggul Sudarmo dan Buku Teks kimia SMA kurikulum 2013 pengarang Endang Susilowati.. Berdasarkan uraian tersebut, maka peneliti perlu mengkaji tentang "Analisis Materi Ajar Kimia SMA/MA Kelas X Pada Konsep Stoikiometri" agar potensi kesalahan konsep atau miskonsepsi pada buku yang ditumbulkan dapat diminimalisir. Berdasarkan latar belakang yang di telah dikemukakan di atas, maka rumusan masalah untuk penelitian ini adalah:

1. Bagaimana kesesuaian konsep Stoikiometri pada Materi Ajar Kimia SMA/MA kelas X terhadap kurikulum 2013?

2. Bagaimana struktur makro wacana pada Materi Ajar Kimia SMA/MA kelas X pada konsep Stoikiometri?

3. Proposisi apa saja yang berpotensi menimbulkan kesalahan konsep yang terdapat dalam Materi Ajar Kimia SMA/MA kelas X pada konsep Stoikiometri?

Penelitaian tentang analisis materi ajar pada buku teks kimia SMA sebelumnya telah dilakukan oleh Wulandari (2019). Penelitian ini bertujuan untuk mendeskripsikan: Kesesuaian konsep Stoikiometri pada Materi Ajar Kimia SMA/MA kelas X terhadap kurikulum 2013, struktur makro wacana dan 
proposisi apa saja yang berpotensi menimbulkan kesalahan konsep yang terdapat dalam Materi Ajar Kimia SMA/MA kelas X pada konsep Stoikiometri.

\section{METODOLOGI PENELITIAN}

Penelitian ini menggunakan jenis penenlitian deskriptif yang bertujuan untuk mendeskripsikan fenomena-fenomena yang ada tetapi tidak mengubah, menambah, atau mengadakan manipulasi terhadap objek atau wilayah tertentu. Hal yang dideskripsikan dalam penelitian ini adalah hasil analisis proposisi mikromakro, analisis struktur makro wacana dan analisis proposisi yang berpotensi menimbulkan kesalahan konsep (miskonsepsi) pada Materi ajar Kimia pada konsep stoikiometri dalam Materi Ajar Pada Buku Teks kimia SMA/MA Kelas X.

Waktu pengumpulan data dimulai pada bulan februari 2019 dan Objek yang menjadi sumber data pada penelitian ini adalah Buku Teks yang dianalisis adalah Buku Teks kimia SMA kurikulum 2013 pengarang Unggul Sudarmo dan Buku Teks kimia SMA kurikulum 2013 pengarang Endang Susilowati.

Instrumen yang digunakan untuk memperoleh data, yaitu: Tabel Identifikasi Label Konsep dan Proposisi Mikro-Makro, Model struktur makro wacana, dan tabel Identifikasi Proposisi yang Berpotensi Miskonsepsi (Kesalahan Konsep) pada konsep stoikiometri dalam Buku Teks SMA

Data penelitian ini berupa konsep stoikiometri yang terdapat pada Buku teks A dan Buku teks B yang dikumpulkan melalui lembar observasi berupa teks asli, teks dasar dan teks asli yang berpotensi miskonsepsi (kesalahan konsep). Langkah-langkah pengumpulan data yaitu sebagai berikut: Teks asli diambil dari masing-masing Buku Teks kimia kurikulum 2013 materi stoikiometri dengan discan menggunakan printer dan diketik pada program Microsoft Word, teks asli yang di discan atau diketik berupa konsep materi stoikiometri, teks asli dimasukan kedalam tabel pembuatan teks dasar, dalam pembuatan teks dasar dilakukan proses penghalusan melalui penghapusan dan penyisipan kata. Teks asli diidentifikasi dengan tabel identifikasi label konsep dengan jenis pengetahuan dan tabel identifikasi penurunan proposisi mikro dan makro. Teks asli konsep dan contoh soal pada materi stoikiometri yang dianalisis ditelaah secara cermat, setelah ditelaah secara keseluruhan pada teks asli dapat ditemukan proposisi yang berpotensi kesalahan konsep. dianalisis ditelaah secara cermat, setelah ditelaah secara keseluruhan pada teks asli dapat ditemukan proposisi yang berpotensi kesalahan konsep, teks asli yang berpotensi kesalahan konsep discan/ diketik pada Microsoft Word, proposisi yang berpotensi menimbulkan kesalahan konsep diidentifikasi dengan menggunakan tabel identifikasi proposisi yang berpotensi kesalahan konsep.

Teknik analisis data dalam penelitian ini dianalisis dengan langkah-langkah sebagai berikut:

a. Teks dasar yang diperoleh dimasukkan kedalam tabel penurunan proposisi mikro dan makro yang melalui proses penghapusan, generalisasi, dan konstruksi.

b. Pada proses penghapusan dilakukan untuk menghilangkan kata-kata yang tidak diperlukan sehingga akan menghasilkan proposisi mikro dan makro.

c. Pada proses generalisasi dapat diturunkan dari proposisi tertentu sehingga dihasilkan proposisi makro yang bersifat umum. 
d. Pada proses konstruksi dapat dihasilkan proposisi baru, yaitu proposisi makro dibangun dari beberapa proposisi mikro.

e. Label konsep (proposisi makro utama) disesuaikan Label konsep (proposisi makro utama) disesuaikan terhadap kurikulum 2013

f. Proposisi makro utama yang dihasilkan akan dilakukan pemetaan kedalam struktur makro wacana.

g. Teks asli yang berpotensi menimbulkan kesalahan konsep, dilakukan analisis dengan cara peneliti memberikan konsepsi peneliti, menunjukkan teks yang berpotensi kesalahan konsep dan alasan mengapa teks tersebut berpotensi kesalahan konsep.

\section{HASIL PENELITIAN DAN PEMBAHASAN}

Penelitian ini akan dijelaskan hasil dan pembahasan mengenai hubungan kesesuaian konsep Stoikiometri pada Materi Ajar Kimia SMA/MA kelas X terhadap kurikulum 2013 struktur makro dalam materi ajar kimia SMA/MA Kelas X pada konsep stoikiometri, dan proposisi yang berpotensi kesalahan

Perbandingan label konsep antara buku teks A dan buku teks B dapat dicermati pada tabel berikut ini:

\begin{tabular}{|c|c|c|c|c|c|}
\hline No & Label Konsep & Buku A & Halaman & Buku B & Halaman \\
\hline 1 & Stoikiometri & $\sqrt{ }$ & 98 & $\sqrt{ }$ & 129 \\
\hline 2 & Massa atom & $\sqrt{ }$ & 98 & $\sqrt{ }$ & 137 \\
\hline 3 & Massa atom rata-rata & - & - & $\sqrt{ }$ & 137 \\
\hline 4 & Satuan massa atom & $\sqrt{ }$ & 99 & $\sqrt{ }$ & 138 \\
\hline 5 & Massa atom Relatif & $\sqrt{ }$ & 100 & $\sqrt{ }$ & 139 \\
\hline 6 & Massa molekul Relatif & $\sqrt{ }$ & 101 & $\sqrt{ }$ & 141 \\
\hline 7 & Persamaan Reaksi & $\sqrt{ }$ & 102 & $\sqrt{ }$ & 168 \\
\hline 8 & Reaktan dan Produk & $\sqrt{ }$ & 102 & & \\
\hline 9 & $\begin{array}{l}\text { Penulisan Persamaan } \\
\text { Reaksi }\end{array}$ & $\sqrt{ }$ & 102 & & \\
\hline 10 & Koefisien Reaksi & $\sqrt{ }$ & 103 & $\sqrt{ }$ & 161 \\
\hline 11 & $\begin{array}{l}\text { Penyetaraan Persamaan } \\
\text { Reaksi }\end{array}$ & $\sqrt{ }$ & $104-105$ & & \\
\hline 12 & $\begin{array}{l}\text { Hukum Kekekalan } \\
\text { Massa }\end{array}$ & $\sqrt{ }$ & $106-107$ & $\sqrt{ }$ & 129 \\
\hline 13 & $\begin{array}{l}\text { Hukum Perbandingan } \\
\text { tetap (Hukum Proust) }\end{array}$ & $\sqrt{ }$ & 109 & $\sqrt{ }$ & 130 \\
\hline 14 & Hukum Dalton & $\sqrt{ }$ & 110 & $\sqrt{ }$ & 133 \\
\hline 15 & $\begin{array}{l}\text { Hukum Perbandingan } \\
\text { Volume (Hukum Gay- } \\
\text { Lussac) }\end{array}$ & $\sqrt{ }$ & 111 & $\sqrt{ }$ & 135 \\
\hline 16 & Percobaan Gay Lussac & $\sqrt{ }$ & 111 & & \\
\hline 17 & $\begin{array}{l}\text { Menghitung Volume } \\
\text { gas reaktan dan produk }\end{array}$ & $\sqrt{ }$ & 113 & & \\
\hline 18 & Hipotesis Avogadro & $\sqrt{ }$ & 114 & $\sqrt{ }$ & \\
\hline 19 & Hukum gas ideal & & & $\sqrt{ }$ & 152 \\
\hline 20 & Persamaan gas ideal & & & $\sqrt{ }$ & 153 \\
\hline 21 & Konsep Mol & $\sqrt{ }$ & 115 & $\sqrt{ }$ & 143 \\
\hline
\end{tabular}




\begin{tabular}{|c|c|c|c|c|c|}
\hline No & Label Konsep & Buku A & Halaman & Buku B & Halaman \\
\hline 22 & Tetapan Avoagadro & & & $\sqrt{ }$ & 146 \\
\hline 23 & Massa Molar & $\sqrt{ }$ & 116 & $\sqrt{ }$ & 147 \\
\hline 24 & $\begin{array}{l}\text { Volume Molar (Kondisi } \\
\text { Standar STP) }\end{array}$ & $\sqrt{ }$ & 117 & $\sqrt{ }$ & 150 \\
\hline 25 & $\begin{array}{l}\text { Volume Molar (Kondisi } \\
\text { RTP) }\end{array}$ & $\sqrt{ }$ & 118 & & \\
\hline 26 & $\begin{array}{l}\text { Menghitung Massa dan } \\
\text { volume produk }\end{array}$ & $\sqrt{ }$ & 119 & & \\
\hline 27 & $\begin{array}{l}\text { Persentase Unsur dalam } \\
\text { senyawa }\end{array}$ & & & $\sqrt{ }$ & 155 \\
\hline 28 & $\begin{array}{l}\text { Kadar zat dalam } \\
\text { campuran }\end{array}$ & & & $\sqrt{ }$ & 156 \\
\hline 29 & $\begin{array}{l}\text { Konsentrasi dan } \\
\text { Kepekatan }\end{array}$ & & & $\sqrt{ }$ & 158 \\
\hline 30 & Konsentrasi Larutan & $\sqrt{ }$ & 120 & & \\
\hline 31 & Persentase Massa & $\sqrt{ }$ & 120 & $\sqrt{ }$ & 160 \\
\hline 32 & Persentase volume & $\sqrt{ }$ & 121 & $\sqrt{ }$ & 160 \\
\hline 33 & $\begin{array}{l}\text { Persentase berat per } \\
\text { volume }\end{array}$ & $\sqrt{ }$ & 121 & $\sqrt{ }$ & 161 \\
\hline 34 & Molaritas & $\sqrt{ }$ & 122 & $\sqrt{ }$ & 161 \\
\hline 35 & Molalitas & & & $\sqrt{ }$ & 162 \\
\hline 36 & Fraksi mol (X) & & & $\sqrt{ }$ & 163 \\
\hline 37 & Pelarutan Zat Murni & $\sqrt{ }$ & 123 & & \\
\hline 38 & Pengenceran & $\sqrt{ }$ & 124 & $\sqrt{ }$ & 164 \\
\hline 39 & $\begin{array}{l}\text { Pencampuran Larutan } \\
\text { dengan Konsentrasi } \\
\text { Berbeda }\end{array}$ & $\sqrt{ }$ & 124 & $\sqrt{ }$ & 166 \\
\hline 40 & $\begin{array}{l}\text { Pembuatan Larutan dari } \\
\text { zat padat }\end{array}$ & & & $\sqrt{ }$ & 166 \\
\hline 41 & $\begin{array}{l}\text { Pembuatan Larutan dari } \\
\text { larutan pekat }\end{array}$ & & & $\sqrt{ }$ & 167 \\
\hline 42 & Bagian per juta (Bpj) & $\sqrt{ }$ & 125 & $\sqrt{ }$ & 161 \\
\hline 43 & $\begin{array}{l}\text { Interkonversi mol- } \\
\text { massa-volume-jumlah } \\
\text { partikel }\end{array}$ & & & $\sqrt{ }$ & 154 \\
\hline 44 & $\begin{array}{l}\text { Rumus molekul dan } \\
\text { rumus empiris }\end{array}$ & $\sqrt{ }$ & 126 & $\sqrt{ }$ & 155 \\
\hline 45 & Air Kristal & $\sqrt{ }$ & 127 & $\sqrt{ }$ & 171 \\
\hline 46 & Pereaksi Pembatas & $\sqrt{ }$ & 127 & $\sqrt{ }$ & 171 \\
\hline
\end{tabular}

\section{Keterangan:}

: label konsep yang terdapat pada buku teks A dan B yang sama

: Label konsep yang hanya terdapat pada buku teks A

: Label konsep yang hanya terdapat pada buku teks B

Label konsep buku teks A dan buku teks B hasil identifikasi pada tabel 13 disesuaikan terhadap kurikulum 2013. Kesesuaian label konsep pada buku teks A dan buku teks B terhadap kurikulum 2013 dapat dicermati pada tabel berikut: 


\begin{tabular}{|c|c|c|c|c|c|c|c|}
\hline \multirow{3}{*}{$\begin{array}{c}\text { Kode } \\
\text { Kompetensi } \\
\text { Dasar }(\text { KD) }\end{array}$} & & \multirow{3}{*}{$\begin{array}{l}\text { Kode } \\
\text { Materi } \\
\text { Pokok }\end{array}$} & \multirow{3}{*}{ Label Konsep } & \multicolumn{4}{|c|}{ Kesesuai dengan Silabus } \\
\hline & & & & \multicolumn{2}{|c|}{$\begin{array}{l}\text { Kompetensi } \\
\text { Dasar (KD) }\end{array}$} & \multicolumn{2}{|c|}{ Materi Pokok } \\
\hline & & & & $\begin{array}{c}\text { Buku } \\
\text { A }\end{array}$ & $\begin{array}{c}\text { Buku } \\
\text { B }\end{array}$ & $\begin{array}{c}\text { Buku } \\
\text { A }\end{array}$ & $\begin{array}{c}\text { Buku } \\
\text { B }\end{array}$ \\
\hline \multirow{6}{*}{$\begin{array}{l}\text { 3.10 Menerapkan } \\
\text { hukum-hukum } \\
\text { dasar kimia, } \\
\text { konsep massa } \\
\text { molekul relatif, } \\
\text { persamaan kimia, } \\
\text { konsep mol, dan } \\
\text { kadar zat untuk } \\
\text { menyelesaikan } \\
\text { perhitungan kimia }\end{array}$} & \multirow{3}{*}{ a. } & \multirow{3}{*}{$\begin{array}{l}\text { Hukum- } \\
\text { hukum } \\
\text { dasar }\end{array}$} & Stoikiometri & $*$ & $*$ & $*$ & $*$ \\
\hline & & & Massa atom & 3.10 & 3.10 & $\mathrm{~b}$ & $\mathrm{~b}$ \\
\hline & & & $\begin{array}{l}\text { Satuan massa } \\
\text { atom }\end{array}$ & 3.10 & 3.10 & $\mathrm{~b}$ & $\mathrm{~b}$ \\
\hline & b. & $\begin{array}{l}\text { kimia } \\
\text { Massa } \\
\text { atom }\end{array}$ & $\begin{array}{l}\text { Massa atom } \\
\text { Relatif }\end{array}$ & 3.10 & 3.10 & $\mathrm{~b}$ & $\mathrm{~b}$ \\
\hline & & $\begin{array}{l}\text { relatif } \\
\text { (Ar) dan }\end{array}$ & $\begin{array}{l}\text { Massa molekul } \\
\text { Relatif }\end{array}$ & 3.10 & 3.10 & $\mathrm{~b}$ & $\mathrm{~b}$ \\
\hline & & $\begin{array}{l}\text { Massa } \\
\text { molekul }\end{array}$ & $\begin{array}{l}\text { Persamaan } \\
\text { Reaksi }\end{array}$ & 3.10 & 3.10 & $\mathrm{c}$ & $\mathrm{c}$ \\
\hline $\begin{array}{l}\text { 4.10 Menganalisis } \\
\text { data hasil }\end{array}$ & & $\begin{array}{l}\text { relatif } \\
(\mathrm{Mr})\end{array}$ & $\begin{array}{l}\text { Koefisien } \\
\text { Reaksi }\end{array}$ & 3.10 & 3.10 & $\mathrm{c}$ & $\mathrm{c}$ \\
\hline percobaan & c. & Persamaan & Hukum & & & & \\
\hline menggunakan & & Kimia & Kekekalan & 3.10 & 3.10 & $\mathrm{a}$ & $\mathrm{a}$ \\
\hline $\begin{array}{l}\text { hukum-hukum } \\
\text { dasar kimia }\end{array}$ & d. & $\begin{array}{l}\text { Konsep } \\
\text { mol dan }\end{array}$ & $\begin{array}{l}\text { Massa } \\
\text { Hukum }\end{array}$ & & & & \\
\hline & & $\begin{array}{l}\text { hubungan } \\
\text { nya } \\
\text { dengan }\end{array}$ & $\begin{array}{l}\text { Perbandingan } \\
\text { tetap (Hukum } \\
\text { Proust) }\end{array}$ & 3.10 & 3.10 & $\mathrm{a}$ & $\mathrm{a}$ \\
\hline & & $\begin{array}{l}\text { jumlah } \\
\text { partikel, }\end{array}$ & Hukum Dalton & 3.10 & 3.10 & a & $\mathrm{a}$ \\
\hline & & $\begin{array}{l}\text { massa } \\
\text { molar, dan }\end{array}$ & $\begin{array}{l}\text { Hukum } \\
\text { Perbandingan }\end{array}$ & & & & \\
\hline & e. & $\begin{array}{l}\text { volume } \\
\text { molar } \\
\text { Kadar zat }\end{array}$ & $\begin{array}{l}\text { Volume } \\
\text { (Hukum Gay- } \\
\text { Lussac) }\end{array}$ & 3.10 & 3.10 & $\mathrm{a}$ & a \\
\hline & & $\begin{array}{l}\text { Rumus } \\
\text { empiris }\end{array}$ & $\begin{array}{l}\text { Hipotesis } \\
\text { Avogadro }\end{array}$ & 3.10 & 3.10 & $\mathrm{a}$ & $\mathrm{a}$ \\
\hline & & dan rumus & Konsep Mol & 3.10 & 3.10 & d & $\mathrm{d}$ \\
\hline & & $\begin{array}{l}\text { molekul } \\
\text { Kadar dan }\end{array}$ & $\begin{array}{l}\text { Massa Molar } \\
\text { Volume Molar }\end{array}$ & 3.10 & 3.10 & $\mathrm{~d}$ & $\mathrm{~d}$ \\
\hline & & $\begin{array}{l}\text { perhitunga } \\
\text { n kimia }\end{array}$ & $\begin{array}{l}\text { (Kondisi } \\
\text { Standar STP) }\end{array}$ & 3.10 & 3.10 & d & $\mathrm{d}$ \\
\hline & & $\begin{array}{l}\text { untuk } \\
\text { senyawa }\end{array}$ & $\begin{array}{l}\text { Persentase } \\
\text { Massa }\end{array}$ & 3.10 & 3.10 & e & $\mathrm{e}$ \\
\hline & h. & Perhitunga & $\begin{array}{l}\text { Persentase } \\
\text { volume }\end{array}$ & 3.10 & 3.10 & $\mathrm{e}$ & $\mathrm{e}$ \\
\hline
\end{tabular}




\begin{tabular}{|c|c|c|c|c|c|c|c|}
\hline \multirow{3}{*}{$\begin{array}{c}\text { Kode } \\
\text { Kompetensi } \\
\text { Dasar (KD) }\end{array}$} & \multirow{3}{*}{\multicolumn{2}{|c|}{$\begin{array}{l}\text { Kode } \\
\text { Materi } \\
\text { Pokok }\end{array}$}} & \multirow{3}{*}{ Label Konsep } & \multicolumn{4}{|c|}{ Kesesuai dengan Silabus } \\
\hline & & & & \multicolumn{2}{|c|}{$\begin{array}{l}\text { Kompetensi } \\
\text { Dasar (KD) }\end{array}$} & \multicolumn{2}{|c|}{ Materi Pokok } \\
\hline & & & & $\begin{array}{c}\text { Buku } \\
\text { A }\end{array}$ & $\begin{array}{c}\text { Buku } \\
\text { B }\end{array}$ & $\begin{array}{c}\text { Buku } \\
\text { A }\end{array}$ & $\begin{array}{c}\text { Buku } \\
\text { B }\end{array}$ \\
\hline & & $\begin{array}{l}\text { n kimia } \\
\text { dalam }\end{array}$ & $\begin{array}{l}\text { Persentase berat } \\
\text { per volume }\end{array}$ & 3.10 & 3.10 & $\mathrm{e}$ & $\mathrm{e}$ \\
\hline & & suatu & Molaritas & & & & \\
\hline & & $\begin{array}{l}\text { persamaan } \\
\text { reaksi }\end{array}$ & $\begin{array}{l}\text { Pengenceran } \\
\text { Pencampuran }\end{array}$ & 3.10 & 3.10 & $\mathrm{~g}$ & $\mathrm{~g}$ \\
\hline & i. & $\begin{array}{l}\text { Pereaksi } \\
\text { pembatas } \\
\text { dan } \\
\text { pereaksi }\end{array}$ & $\begin{array}{l}\text { Larutan dengan } \\
\text { Konsentrasi } \\
\text { Berbeda }\end{array}$ & 3.10 & 3.10 & $\mathrm{~g}$ & $\mathrm{~g}$ \\
\hline & & berlebih & $\begin{array}{l}\text { Bagian per juta } \\
\text { (bpj) }\end{array}$ & 3.10 & 3.10 & $\mathrm{e}$ & $\mathrm{e}$ \\
\hline & & & $\begin{array}{l}\text { Rumus molekul } \\
\text { dan rumus } \\
\text { empiris }\end{array}$ & 3.10 & 3.10 & $\mathrm{f}$ & $\mathrm{f}$ \\
\hline & & & Air kristal & 3.10 & 3.10 & $\mathrm{~g}$ & $\mathrm{~g}$ \\
\hline & & & $\begin{array}{l}\text { Pereaksi } \\
\text { Pembatas }\end{array}$ & 3.10 & 3.10 & $\mathrm{i}$ & $\mathrm{i}$ \\
\hline & & & $\begin{array}{l}\text { Reaktan dan } \\
\text { Produk } \\
\text { Penulisan }\end{array}$ & 3.10 & & $\mathrm{c}$ & \\
\hline & & & $\begin{array}{l}\text { Persamaan } \\
\text { Reaksi } \\
\text { Penyetaraan }\end{array}$ & 3.10 & & $\mathrm{c}$ & \\
\hline & & & $\begin{array}{l}\text { Persamaan } \\
\text { Reaksi }\end{array}$ & 3.10 & & $\mathrm{c}$ & \\
\hline & & & $\begin{array}{l}\text { Percobaan Gay } \\
\text { Lussac }\end{array}$ & 3.10 & & $\mathrm{a}$ & \\
\hline & & & $\begin{array}{l}\text { Menghitung } \\
\text { volume gas } \\
\text { reaktan dan } \\
\text { produk }\end{array}$ & 3.10 & & $\mathrm{~h}$ & \\
\hline & & & $\begin{array}{l}\text { Volume molar } \\
\text { (kondisi RTP) }\end{array}$ & 3.10 & & $\mathrm{~d}$ & \\
\hline & & & $\begin{array}{l}\text { Menghitung } \\
\text { massa dan } \\
\text { volume produk }\end{array}$ & 3.10 & & $\mathrm{~h}$ & \\
\hline & & & $\begin{array}{l}\text { Konsentrasi } \\
\text { larutan }\end{array}$ & 3.10 & & $\mathrm{e}$ & \\
\hline & & & $\begin{array}{l}\text { Pelarutan zat } \\
\text { murni }\end{array}$ & 3.10 & & $\mathrm{e}$ & \\
\hline & & & $\begin{array}{l}\text { Massa atom } \\
\text { rata-rata }\end{array}$ & & 3.10 & & $\mathrm{~b}$ \\
\hline
\end{tabular}




\begin{tabular}{|c|c|c|c|c|c|c|}
\hline \multirow{3}{*}{$\begin{array}{c}\text { Kode } \\
\text { Kompetensi } \\
\text { Dasar }(\text { KD) }\end{array}$} & \multirow{3}{*}{$\begin{array}{l}\text { Kode } \\
\text { Materi } \\
\text { Pokok }\end{array}$} & \multirow{3}{*}{ Label Konsep } & \multicolumn{4}{|c|}{ Kesesuai dengan Silabus } \\
\hline & & & \multicolumn{2}{|c|}{$\begin{array}{l}\text { Kompetensi } \\
\text { Dasar (KD) }\end{array}$} & \multicolumn{2}{|c|}{ Materi Pokok } \\
\hline & & & $\begin{array}{c}\text { Buku } \\
\text { A }\end{array}$ & $\begin{array}{c}\text { Buku } \\
\text { B }\end{array}$ & $\begin{array}{c}\text { Buku } \\
\text { A }\end{array}$ & $\begin{array}{c}\text { Buku } \\
\text { B }\end{array}$ \\
\hline & & $\begin{array}{l}\text { Hukum gas } \\
\text { ideal }\end{array}$ & & 3.10 & & $\mathrm{~d}$ \\
\hline & & $\begin{array}{l}\text { Persamaan gas } \\
\text { ideal }\end{array}$ & & 3.10 & & $\mathrm{~d}$ \\
\hline & & $\begin{array}{l}\text { Tetapan } \\
\text { Avogadro }\end{array}$ & & 3.10 & & $\mathrm{~d}$ \\
\hline & & $\begin{array}{l}\text { Persentase } \\
\text { unsur dalam } \\
\text { senyawa }\end{array}$ & & 3.10 & & $\mathrm{~g}$ \\
\hline & & $\begin{array}{l}\text { Kadar zat dalam } \\
\text { campuran }\end{array}$ & & 3.10 & & $\mathrm{~g}$ \\
\hline & & $\begin{array}{l}\text { Konsentrasi dan } \\
\text { kepekatan }\end{array}$ & & 3.10 & & $\mathrm{~g}$ \\
\hline & & Molalitas & & 3.10 & & $\mathrm{~d}$ \\
\hline & & Fraksi mol (X) & & 3.10 & & $\mathrm{~d}$ \\
\hline & & $\begin{array}{l}\text { Pembuatan } \\
\text { larutan dari zat } \\
\text { padat }\end{array}$ & & 3.10 & & $\mathrm{e}$ \\
\hline & & $\begin{array}{l}\text { Pembuatan } \\
\text { larutan dari } \\
\text { larutan pekat }\end{array}$ & & 3.10 & & $\mathrm{e}$ \\
\hline & & $\begin{array}{l}\text { Interkonversi } \\
\text { mol-massa- } \\
\text { volume-jumlah } \\
\text { partikel }\end{array}$ & & 3.10 & & $\mathrm{~d}$ \\
\hline
\end{tabular}

Keterangan:

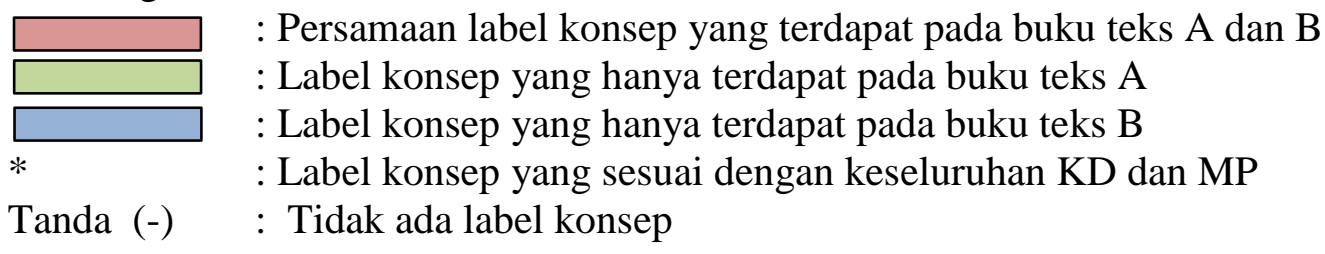

Struktur makro dibentuk dengan menggunakan dimensi progresi dan dimensi elaborasi. Dimensi progresi mengalurkan proposisi menurut realisasi motif sedangkan dimensi organisasi diperankan oleh dimensi elaborasi yang mengatur hubungan organisasi struktur makro dan struktur mikro. Bagan struktur makro untuk buku A dapat di lihat pada bagan berikut ini

Hasil dari penurunan struktur makro topik stoikiometri pada buku A yaitu sebagai berikut:

a. Empat buah makro utama, yaitu:

P-I = Massa atom

P-II = Persamaan reaksi kimia 
P-III = Hukum Dasar Kimia

P-IV = Perhitungan Kimia

b. Dua puluh delapan makro bawahan, yaitu:

\begin{tabular}{|c|c|c|}
\hline P-1 & $=$ Massa atom realtif & P-18 = Konsentrasi larutan \\
\hline P-2 & $=$ Massa molekul realtif & $\mathrm{P}-19=$ Persentase massa \\
\hline P-3 & $\begin{aligned}= & \text { Penulisan persamaan } \\
& \text { reaksi }\end{aligned}$ & $\begin{array}{l}\mathrm{P}-20=\text { Persentase Volume } \\
\mathrm{P}-21=\text { Persentase Berat per }\end{array}$ \\
\hline P-4 & $=$ Reaktan & volume \\
\hline P-5 & $=$ Produk & $\mathrm{P}-22=$ Molaritas \\
\hline P-6 & $\begin{aligned}= & \text { Penyetaraan Persamaan } \\
& \text { Reaksi }\end{aligned}$ & $\begin{array}{l}\mathrm{P}-23=\text { Pelarutan zat murni } \\
\mathrm{P}-24=\text { Pengenceran }\end{array}$ \\
\hline P-7 & $=$ Koefisien reaksi & P-25 = Pencampuran dua \\
\hline P-8 & $\begin{aligned}= & \text { Hukum kekekalan } \\
& \text { Massa }\end{aligned}$ & $\begin{array}{l}\text { larutanyang berbeda } \\
\text { konsentrasinya }\end{array}$ \\
\hline P-9 & $\begin{aligned}= & \text { Hukum Perbandingan } \\
& \text { Tetap }\end{aligned}$ & $\begin{array}{l}\mathrm{P}-26=\text { bagian per juta } \\
\mathrm{P}-27=\text { Rumus empiris }\end{array}$ \\
\hline P-10 & = Hukum Dalton & P-28 = Rumus molekul \\
\hline P-11 & = Hukum Gay Lussac & P-29 = Air kristal \\
\hline P-12 & $=$ Hipotesis Avogadro & P-30 = Pereaksi pembatas \\
\hline P-13 & $\begin{aligned}= & \text { Perhitungan volume } \\
& \text { gas dan reaktan }\end{aligned}$ & \\
\hline P-14 & $=$ Konsep mol & \\
\hline P-15 & = Massa molar & \\
\hline P-16 & $=$ Volume molar & \\
\hline P-17 & $\begin{aligned}= & \text { Penentuan massa dan } \\
& \text { volume produk }\end{aligned}$ & \\
\hline
\end{tabular}

Struktur makro dibentuk dengan menggunakan dimensi progresi dan dimensi elaborasi. Dimensi progresi mengalurkan proposisi menurut realisasi motif sedangkan dimensi organisasi diperankan oleh dimensi elaborasi yang mengatur hubungan organisasi struktur makro dan struktur mikro. Bagan struktur makro untuk buku B dapat di lihat pada bagan dibawah ini.

Hasil dari penurunan struktur makro topik stoikiometri pada buku B yaitu sebagai berikut:

a. Delapan buah makro utama, yaitu:

P-I = Hukum dasar kimia

P-II = Massa atom

P-III = Konsep mol

P-IV = Hukum tentang gas

$\mathrm{P}-\mathrm{V}=$ Interkonversi mol-massa-volume dan jumlah partikel

P-VI = Perhitungan Kimia

P-VII = Kadar zat dalam campuran

P-VIII = Persamaan reaksi

b. Tiga puluh dua makro bawahan, yaitu:

$\begin{array}{rlrl}\text { P-1 } & \text { Hukum kekakalan massa } \\ \text { P-2 } & \text { Hukum Perbandingan } & \text { P-18 } & =\text { Rumus empiris } \\ & \text { Tetap } & \text { P-19 } & \begin{array}{l}\text { Persentase unsur dalam } \\ \text { senyawa }\end{array}\end{array}$




\begin{tabular}{|llll|}
\hline P-3 & = Hukum Dalton & P-20 & $=$ Persentase massa \\
P-4 & = Hukum Gay-lussac & P-21 & $=$ Persentase volume \\
P-5 & = Hipotesis Avogadro & P-22 & $=$ Bagian per juta \\
P-6 & = Massa atom rata-rata & P-24 & $=$ Molaritas \\
P-7 & $=$ Satuan massa atom & P-25 & $=$ Molalitas \\
P-8 & $=$ Massa atom relatif & P-26 & $=$ Fraksi mol \\
P-9 & = Massa molekul relatif & P-27 & $=$ Pengenceran larutan \\
P-10 = Massa molar & P-28 & $=$ Pencampuran lrutan dengan \\
P-11 = Volume molar & & konsentrasi berbeda \\
P-12 = Hukum gas ideal & P-29 & $=$ Pembuatan larutan dari zat \\
P-13 = Persamaan gas ideal & & padat \\
P-14 =Interkoversi mol-massa & P-30 & $=$ Pembuatan larutan dari \\
P-15 = Interkonversi mol-volume & & larutan pekat \\
P-16 = Interkonversi mol-jumlah & P-31 & $=$ Reaktan \\
& Partikel & P-32 & $=$ Produk \\
P-17 $=$ Rumus molekul & P-33 & $=$ Koefisien reaksi \\
& & P-34 & $=$ Air kristal \\
& & P-35 & $=$ Reaksi Pembatas
\end{tabular}

Buku teks A mempunyai beberapa konsep baik dari segi bahasa dan penulisan maupun contoh soal yang disajikan di dalam buku yang dapat berpotensi kesalahan konsep (miskonsepsi). Proposisi yang berpotensi kesalahan konsep (miskonsepsi) yaitu pada contoh soal mengenai hukum perbandingan volume, pada contoh soal tersebut tidak dituliskan satuan dari massa yang akan dihitung yang mana disajikan dalam Gambar 1.

1. Analisis terhaday dua cuplikan garam dapur didapat data sebagai berikut.

\begin{tabular}{|l|c|c|c|}
\hline Cuplikan & $\begin{array}{c}\text { Massa } \\
\text { Garam (g) }\end{array}$ & $\begin{array}{c}\text { Massa Natrium } \\
\text { yang Diperoleh (g) }\end{array}$ & $\begin{array}{c}\text { Massa Klorin } \\
\text { yang Diperoleh (g) }\end{array}$ \\
\hline Cuplikan 1 & 0,2925 & 0,1150 & 0,1775 \\
Cuplikan 2 & 1,755 & 0,690 & 1,065 \\
\hline
\end{tabular}

Tunjukkan bahwa data itu sesuai dengan hukum Proust. Jawaban:

Persentase natrium dalam cuplikan 1

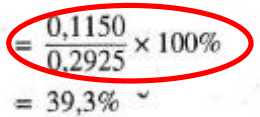

Gambar 1. Proposisi berpotensi miskonsepsi

Tidak dituliskannya satuan gram (g) menyebabkan miskonsepsi pada siswa karena gram (g) menyatakan hasil pengukuran yang merupakan besaran massa dalam sistem internasional atau disingkat SI dan sistem metriks kecil atau CGS (Centimeter Gram Second), untuk menghindari hal tersebut sebaiknya dalam penulisan dalam menjawab soal untuk satuan dari setiap besaran harusnya dicantumkan (dapat dicermati dalam contoh dibawah ini) sehingga tidak menimbulkan miskonsepsi pada siswa.

Persentase Na dalam cuplikan

$$
=\frac{\text { massa natrium yang diperoleh }(\text { gram })}{\text { massa garam }(\text { gram })} \times 100 \%
$$


Persentase Na dalam cuplikan $=\frac{0,1150 \mathrm{gram}}{0,2925 \mathrm{gram}} \times 100 \%$

Persentase natrium dalam cuplikan $=39,3 \%$

(Sunarya, 2000)

Buku teks B mempunyai beberapa konsep baik dari segi bahasa dan penulisan maupun contoh soal yang disajikan di dalam buku yang dapat berpotensi kesalahan konsep (miskonsepsi). Salah satunya dalam paragraf yang membahas tentang hukum kekekalan massa mengandung konsep yang berpotensi kesalahan konsep, yaitu tepatnya pada konsep dalam paragraf kedua, penulisan untuk senyawa merkuri (II) oksida ditulis merkuri oksida dan tidak dituliskan juga rumus molekulnya, hal ini yang dapat menimbulkan kesalahan konsep (miskonsepsi) pada siswa, untuk mencermati kesalahan tersebut dapat dicermati pada Gambar 2.

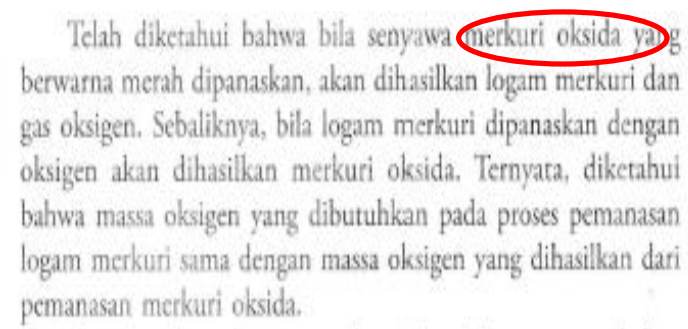

Gambar 2. Proposisi berpotensi miskonsepsi

Merkuri (II) Oksida dengan rumus molekul $\mathrm{HgO}$ merupakan senyawa yang berbentuk pada pada suhu dan tekanan ruang yang memiliki warna merah atau jingga. Penulisan nama senyawa merkuri oksida dapat menyebabkan kesalahan konsep karena kesalahan dalam penulisan serta tidak dicantumkan rumus kimia atau rumus molekulnya, untuk menghindari miskonsepsi penulisan untuk senyawa merkuri oksida adalah merkuri (II) oksida dan rumusmolekulnya yaitu $\mathrm{HgO}$.

\section{SIMPULAN}

Label konsep yang dianalisis secara keseluruhan berjumlah 46 label konsep, label konsep pada buku teks A dan buku teks B yang sesuai terhadap silabus kurikulum 2013 masing-masing berjumlah 34 dan 37. Label konsep yang sama antara buku teks A dan buku teks B berjumlah 25, label konsep yang hanya terdapat pada buku A berjumlah 9 dan label konsep yang hanya terdapat pada buku B, dan semuanya sesuai terhadap silabus kurikulum 2013. Topik stoikiometri berdasarkan struktur makro wacana pada buku teks A pembahasan konsep pada dimensi elaborasi mencapai level 5 yaitu pelarutan zat murni, pengenceran, dan pencampuran dua larutan yang berbeda, dan pada dimensi progresi terdapat 4 konsep pada level, pada buku teks B sajian materi pada dimensi elaborasi mencapai level 4, yaitu satuan massa atom dan persamaan gas ideal, dan pada dimensi progresi pada level 2 terdapat 8 konsep. Proposisi yang berpotensi kesalahan konsep pada buku teks A yang dibahas, yaitu: konsep hukum perbandingan tetap, tetapan Avogadro, konsep massa molar, contoh soal tentang satuan pada volume molar, contoh soal konsep mol, satuan gram (g) pada konsep mol, dan molaritas, konsep pelarutan zat murni dan satuan pada bagian per juta. Proposisi yang berpotensi kesalahan konsep pada buku teks B yang dibahas, yaitu: 
konsep hukum kekekalan massa, contoh soal, hukum Proust, konsep massa molar, contoh soal konsep mol, satuan pada konsep mol, konsep interkonversi mol dan volume, konsep molaritas dan molalitas, konsentrasi larutan dan contoh soal fraksi mol

\section{DAFTAR PUSTAKA}

Ahmad S. 2011. Strategi Pembelajaran Sekolah Terpadu. Jakarta: Prestasi Pustaka Publiaher.

Arifin.2008. Pembuatan Hyperteks Akademik pada Materi Kajian Kecepatan Reaksi dan Pemanfaatannya Sebagai Media Pembelajaran Kimia di SMA. Palangka Raya: Universitas Palangka Raya.

Berg. J Van Den and Meester R.W. J. 1991. Stability properties of a flow process in graphs. Journal Random Structures and Algorithms.

. Chemistry Education Research and Practice Vol. 8.

Dekdikbud. 2007. Model Penilaian Kelas. Jakarta: BSNP (Badan Standar Nasional Pendidikan).

Eriyanto. 2001. Analisis Wacana: Pengantar Analisis Teks Media. Jogyakarta: Lkis.

Gagne, RM dan RJ Briggs. 1997. Condition of Learnig (Kondisi Belajar). New York: Holt Rinehard and Winston, Internasional Journal.

Gkitzia, V., Salta, K., dan Tzougraki, C. 2011. Development and application of suitable criteria for the evaluation of chemical representations in school textbooks. Journal of The Royal Society of Chemistry, 12, 5-14.

Hasan, S., Bagayoko, D., \& Ella, L. K.1999. Misconceptions and the Certainty of Response Index (CRI). Phys. Educ, 34(5), 294-299. https://doi.org/10.1088/0031-9120/34/5/304

Huddle, P. A. White, M.A. \& Rogers, F. 2000. Using a Teaching Model to Correct Known Misconception in Electrochemitry. Journal of Chemical Education, Vol 77 (1): 104-110.

Majid Abdul, \& Chaerul Rochman. 2014. Pendekatan Ilmiah dalam Implementasi Kurikulum 2013. Bandung: PT Remaja Rosdakarya

Meyasi, Yelli. 2016. Kesulitan Siswa Kelas X SMA Negeri 1 Murung dan SMA Negeri Gunung Timang Tahun Ajaran 2014/2015 Dalam Memahami Hukum-Hukum Dasar Kimia. Skripsi Sarjana, tidak dierbitkan. Palangka Raya: Universitas Palangka Raya

Permendikbud. 2015. Peraturan menteri Pendidikan dan Kebudayaan Republik Indonesia Nomor 53 Tahun 2015 Tentang Penilaian Hasil Belajar Oleh 
Pendidik dan Satuan Pendidikan Pada Pendidikan Dasar dan Pendidikan Menengah. Jakarta:BSNP.

Petrucci, R. H. 1985. Kimia Dasar Prinsip dan Terapan Modern Edisi Keempat Jilid 2. Jakarta: Erlangga.

Siregar, N. 1994. Studi Penenrapan Pedagogi Materi Subyek dalam Penulisan Buku Teks MIPA untuk Mengembangkan Keterampilan Intelektual Mahasiswa IKIP Bandung. Bandung: FMIPA IKIP.

Sukmadinata, Nana Syaodih., dan Erliana S. 2012. Kurikulum dan Pembelajaran Kompetensi. Bandung: Refika Aditama

Sunarya, Y. 2000 . Kimia Dasar 1: Bedasarkan Prinsip-prinsip Kimia Terkini. Bandung: Angkasa.

Sunarya, Y. 2010 . Kimia Dasar 1: Bedasarkan Prinsip-prinsip Kimia Terkini. Bandung: Yrama Widya.

Tekkaya, C. 2002. Misconceptions As Barrier To Understanding Biology. Hacettepe Onoversities Egitim Fakultesi Dergisi, 23, 259-266.

Tarigan, H Guntur. 1986. Membaca Sebagai Suatu Keterampilan Berbahasa. Bandung: Angkasa.

Tarigan, H. G. dan Taringan, D. 2009. Telaah Buku Teks Bahasa Indonesia. Bandung: Angkasa.

Wulandari, S.H., Fatah, A.H. and Anggraeni, M.E. 2019. Analisis Materi Ajar Kimia SMA/MA Kelas XII Pada Konsep Sifat Koligatif Larutan. Jurnal Ilmiah Kanderang Tingang. 10, 2 (Des. 2019), 300-320. 